\title{
The Acceptance of E-Learning Among Distance Learners: A case study on public universities in South Malaysia
}

\author{
Nurul Aien Abd Aziz'1, Mohd Hafizan Musa², Rusnani Mohamad Khalid², \\ Noreen Noor Abd Aziz' ${ }^{1}$, Shaherah Abdul Malik ${ }^{1}$ \\ 1 Faculty of Business Management, Universiti Teknologi MARA Johor, Malaysia \\ ${ }^{2}$ Faculty of Computer and Mathematical Sciences, Universiti Teknologi MARA Johor, Malaysia \\ nurul106@uitm.edu.my, mohdh233@uitm.edu.my, rusna162@uitm.edu.my, \\ noree974@uitm.edu.my, shahe314@uitm.edu.my
}

Tel:+6013-7142713

\begin{abstract}
Today's conventional teaching and learning methods have changed due to the COVID-19 pandemic. Online forms are replacing traditional education approaches. Along with the era of advanced technology, many universities are taking this opportunity to develop e-learning platforms to be used by both students and educators. This paper analyses the relationships between student behaviour, technological systems, interactive applications, institutional factors, and instructor characteristics to accept electronic learning among distance learners. A total of 479 valid questionnaires were analyzed. The result indicates that student behaviour, interactive applications, and instructor characteristics are the determinants of electronic learning.
\end{abstract}

Keywords: Acceptance, online learning, Behavior, Distance learners

eISSN: 2398-42870 2021. The Authors. Published for AMER ABRA cE-Bs by e-International Publishing House, Ltd., UK. This is an open access article under the CC BYNC-ND license (http://creativecommons.org/licenses/by-nc-nd/4.0/). Peer-review under responsibility of AMER (Association of Malaysian Environment-Behaviour Researchers), ABRA (Association of Behavioural Researchers on Asians/Africans/Arabians) and CE-Bs (Centre for Environment-Behaviour Studies), Faculty of Architecture, Planning \& Surveying, Universiti Teknologi MARA, Malaysia.

DOI: https://doi.org/10.21834/ebpj.v6i16.2701

\subsection{Introduction}

Nowadays, most higher learning institutions have begun to shift into the use of technology for knowledge delivery. Technology is not a new phenomenon in education since it has already been practiced at the global level. Technology is related mutually with the use of computers, software, systems, platform and mechanism (Mishra \& Koehler, 2007). Educators are rely more on verbal components such as speech, body language, facial expression, and body gestures to provide students with information and awareness before the era of technology began. The traditional learning method of face-to-face interactions have been used for such a long time, and shift to online modes are a new experience for the students. Most universities have their e-learning platforms, and it became one of the essential platforms of e-learning in Malaysia (Poon et al., 2004). The functions of e-learning are defined by their contexts and environments (Asabere \& Enguah, 2012). In another perspective, e-learning is described by Masrom (2007) as a learning aid that is intensified through the use of ICTs (Information and Communication Technologies) in various areas. Differently, Al-Adwan and Smedley (2012) stated that educational processes are structured to enhance learning efficiency. Students can visually see and document them by using the elearning framework. The use of the e-learning system will also help students in completing their task and assignments (Shepherd \& Mullane, 2010). The existence of the COVID-19 pandemic has changed the pattern and landscape of the educational field. Previously,

eISSN: 2398-4287@ 2021. The Authors. Published for AMER ABRA cE-Bs by e-International Publishing House, Ltd., UK. This is an open access article under the CC BYNC-ND license (http://creativecommons.org/licenses/by-nc-nd/4.0). Peer-review under responsibility of AMER (Association of Malaysian Environment-Behaviour Researchers), ABRA (Association of Behavioural Researchers on Asians/Africans/Arabians) and cE-Bs (Centre for Environment-Behaviour Studies), Faculty of Architecture, Planning \& Surveying, Universiti Teknologi MARA, Malaysia.

DOI: https://doi.org/10.21834/ebpj.v6i16.2701 
learning methods using face to face interactions were conducted in classrooms. However, the impact of the COVID-19 pandemic has changed today's conventional teaching and learning methods, as they have been replaced by online learning. This change is a new form of revolution in teaching and learning styles that are different from the traditional methods. The use of e-learning is the best exposure and approach for students, but sometimes some disruptions hinder the process (Abd Aziz et al., 2020). According to Saade (2003), some obstacles contribute to the effectiveness of e-learning, such as student acceptance. Technology does not necessarily lead to an improvement in education (Stephenson, 2001). Hence, the acceptance and preparation of the students are essential to ensure the educational objectives are achieved through e-learning (Aziz, Musa, Ghul, Aziz, \& Khalid, 2018). Therefore, developers of e-learning systems need to understand student acceptance through e-learning systems (Koohang \& Durante, 2003). To implement this, it is necessary to investigate the students' behavioural intentions in accepting it (Grandon, Alshare, \& Kwun, 2005). According to James (2003), many higher education institutions have struggled to maintain this method in the long term because certain hurdles need to be addressed, such as the delivery, quality and acceptance of the course. Besides, it would lead to the failure to fulfil the university's practical strategies and goals of using this system well in the learning process. The failure of the institution to identify the contributing factors to this problem will also disrupt the process of imparting knowledge to students by educators. As a result, students will face difficulties in gaining experience and eventually students will lose motivation besides interest to continue their studies. Hence,the research objective is to examine the relationships between student behaviour, technological systems, interactive applications, institutional factors, and instructor characteristics with the acceptance of e-learning among distance learners. This study will benefit university managements in improving their online teaching methods in the future. By identifying the contributing factors affected students' acceptance of online learning, the management of university can assist the educators in understanding the needs and wants of the students in exact manner.

\subsection{Literature Review}

Since digital learning will keep spreading its wings, there will be a significant need for competent online instructors to make e-learning more attractive. Developing web educators and the disbursement of staff preparation and advancement are attentive needs to build up institutional skills for virtual conduct (Gregory \& Lodge, 2015). Online educator status holds a similar significant build with the consideration of investigating the accessibility of online understudy (Oomen-Early and Murphy, 2009). There is an agreement in earlier writing that the web guidance requires a more adaptable way to deal with the developmental capability because of the assortment of jobs and abilities applied in the online settings (Bawane \& Spector, 2009). It is difficult for the instructors to project the message to the learners through an online medium as it requires more processes to make the learners pay attention to the lesson. The environment is different from being in a classroom where instructors can be more alert to the learners via face-to-face, and the responses are likely to be higher. Albeit that, educators can enhance and motivate students to adapt to e-learning environments (Ndubisi, 2004; Ndubisi \& Chukwunonso, 2004). The assortment of online gear system programmes focuses on the intake of educators' capability specialization utilizing online learning structure (Volery \& Lord, 2000). Presentation skills are also very crucial. Effective communication between educators and students in online learning depends on opportune and understandable forms across styles like e-mail, chat, and many more (Easton, 2003).

Students' perception helps administrations become central in harsh online conditions, where interruptions to innovation or the absence of help from the administrations can represent a critical boundary to understudy commitment in learning. Student support systems are essential in initiation of e-learning methods. Interruptions and constraints of support systems can reduce barriers for students to continue their learning sessions. To ensure effective e-learning, institutions need to offer and provide adequate support systems that are appropriate for online learning. This online-based learning cycle can be implemented well by educators and students; it also depends on the facilities provided by educational institutions in the accomplishment of online learning methods (Pullan, 2011). It is huge for the university to authorize a few endeavours to adapt to this issue by giving backings to the understudies and advance positive psychological wellness (Regehr, 2013). The satisfaction and progress of the students in virtual learning depend on technology and support facilities and infrastructures provided by their institutions (Passmore, 2000).

Today, life without technology is beyond comprehension. Among the significant factors of e-learning acceptance among distance learner, is technology and systems. Internet technologies have changed the systems of education from conventional to online teaching methods. They move from being passive recipients of contents to become more active participants in e-learning. Technology Virtual learning allows students to have flexible study hours in engaging with their educators anywhere. They do not have to travel (Hong, 2003) even when having to do some other work (Sankar, 2020). According to Folorunso et al. (2006), the latest technology used, and a wellmaintained system will affect students' acceptance in e-learning. It supported by Rafaeli and Sudweeks (1997) who stated that students had better acceptance of online learning and will study better if the technology and communication used were effective. Cater to this, during online classes, management of university should provide better technological facilities, accreditation systems, and support from the technical department (Poon et al., 2004). Other than that, the instructors should also be trained with internet technology as it could affect the learning process and assist them in creating conducive e-learning environments. Hong et al. (2003) stated that the use of colours, background settings, graphics, animations, and user-friendliness of an e-learning system with lyrical content on its website would enhance students' interests in learning (Sicilia, 2005). Besides, for educators, the e-learning platform is very interactive if the course contents can be presented with visual aids and interactions with teaching and learning (Tomas et al., 2019).

Interactive applications used in institutions provide personalized adaptive contents to enhance learners' learning effectiveness. Interactive applications offer learners with different forms of approaches to match their learning styles - various courses have various methods (Khamparia \& Pandey, 2017). Interactive e-learning features improve students' motivation for learning processes. According 
to Khamparia and Pandey (2017), interactive applications used in e-learning allow learners to learn anytime and anywhere through various online platforms. It also benefits to the cautious students in the learning process because they have much time and space to grasp all the information from educators. With the exchange of resources and opinions among the students and the instructors, they could learn more conformable better. In addition, the learning process will be easier and manageable because students can access all the information, videos and notes provided by the instructors whenever they want. In e-learning approach, the course must be equipped with digital resources to capture the learners' interests in learning, and understand the concepts (Khamparia \& Pandey, 2017; Sankar et al., 2020).

Furthermore, good e-learning course designs facilitate collaboration, and during their learning process, the learners could find an enjoyable and pleasant environment (Liao et al., 2019). Zhang et al. (2004) claimed that instead of only text-based materials only, the self-instructional materials or learning packages available on the course website should include a multimedia presentation or animation and narration. However, the course design for e-learning can use minimal multimedia contents due to time constraints (Sankar, 2020). The technology can change the classroom and engage the student's behaviour more efficiently and simultaneously it can remove the need for a theoretically based organized, content-driving learning process. A suitable pedagogy must be assisted by technology-based resources to be effective (Laurillard, 2002). Several studies were performed to understand the e-learning adoption using the TAM model (Lee, 2006; Selim, 2003).

Fig.1: Theoretical framework

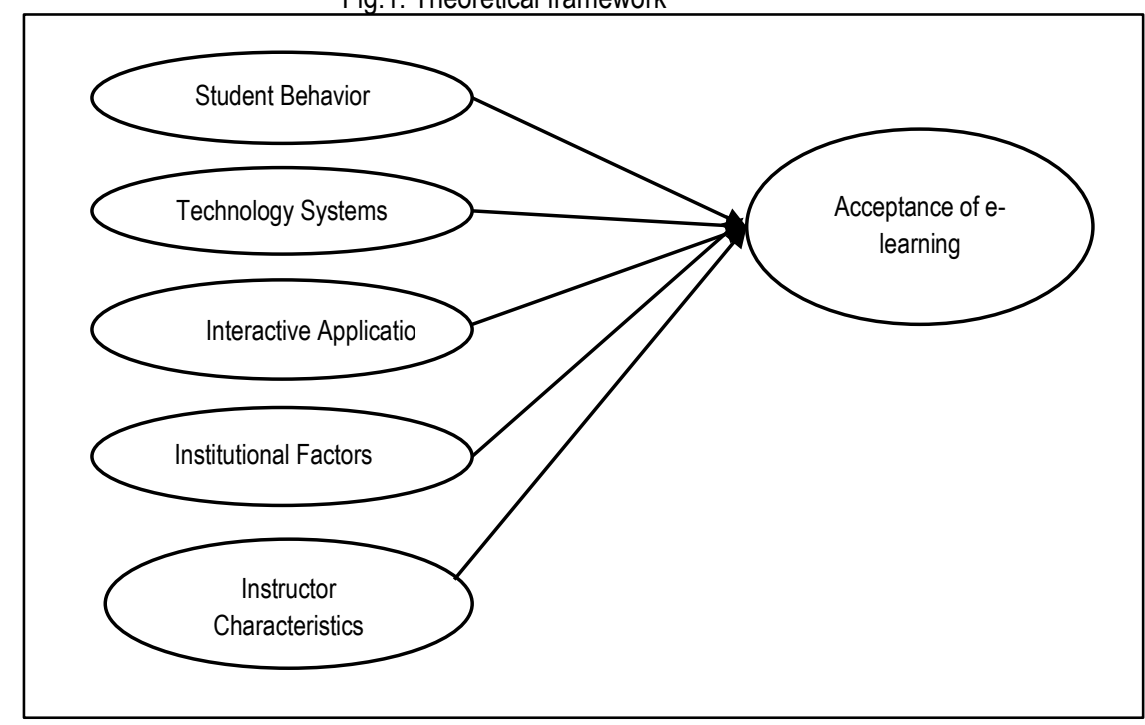

\subsection{Methodology}

This study employed descriptive research and used a questionnaire to gather the data which the questionnaire was personally administrated by the researcher. Respondents were asked to assess the factors towards acceptance on online learning at 5-point likert ( $1=$ strongly disagree and $5=$ strongly agree). Simple random sampling technique is employed in selecting the prospective respondents. Cross-sectional surveys will use questionnaires to obtain the required data. A total of 479 respondents comprising of all South Malaysian university students, or more precisely, to students of Universiti Teknologi MARA (UiTM) Johor, Universiti Teknologi MARA (UiTM) Melaka, Universiti Teknologi MARA (UiTM) Negeri Sembilan, Universiti Teknikal Malaysia Melaka (UTeM), Universiti Tun Hussein Onn Malaysia (UTHM) and Universiti Teknologi Malaysia (UTM). The questionnaires were distributed starting from 16th January 2021 until 20th January 2021.To ensure a high response rate, the researcher has monitored the distribution process of the questionnaire until completed. The data gained from the survey were analysed using Social Science Statistics Package version 25 (SPSS). Besides using descriptive statistics, this study also employed a Pearson correlation to test and investigate the variables' relationships. To examine the reliability and validity, Cronbach's Alpha were used, and the result for alpha showed that the overall scores are in between 0.843 to 0.954 , indicating that they are acceptable.

\subsection{Findings}

\subsection{Profile of Respondents}

Table 1: Demographic Profile $(n=479)$

\begin{tabular}{lccc}
\hline & Categories & Frequency & Percentage (\%) \\
\hline Gender & Female & 367 & 76.6 \\
\hline & Male & 112 & 23.4 \\
\hline
\end{tabular}




\begin{tabular}{|c|c|c|c|}
\hline \multirow[t]{4}{*}{ Age } & $18-20$ & 227 & 47.4 \\
\hline & $21-30$ & 242 & 50.5 \\
\hline & $31-40$ & 6 & 1.3 \\
\hline & $41-50$ & 4 & 0.8 \\
\hline \multirow[t]{6}{*}{ Universities } & UiTM Johor & 172 & 35.9 \\
\hline & UiTM Melaka & 176 & 36.7 \\
\hline & UiTM Negeri Sembilan & 39 & 8.1 \\
\hline & UTeM & 50 & 10.4 \\
\hline & UTHM & 18 & 3.8 \\
\hline & UTM & 24 & 5.0 \\
\hline \multirow[t]{2}{*}{ Education Level } & Degree & 257 & 53.7 \\
\hline & Diploma & 222 & 46.3 \\
\hline \multirow[t]{2}{*}{ Study Mode } & Full-time Study & 452 & 94.4 \\
\hline & Part-time Study & 27 & 5.6 \\
\hline \multirow[t]{6}{*}{ Field of Study } & Arts & 1 & 0.2 \\
\hline & Business & 243 & 50.7 \\
\hline & Education of Graduate \& Professional Studies & 49 & 10.2 \\
\hline & Integrative Studies & 18 & 3.8 \\
\hline & IT \& Computer Sciences & 161 & 33.6 \\
\hline & Nursing & 7 & 1.5 \\
\hline
\end{tabular}

In general, the respondents who participated in this study were female students $(76.6 \% ; 367)$ - more than the male students $(23.4 \%$; 112). Most of the participants mainly aged among 21 years old until 30 years old (50.5\%; 242), followed by those aged 18 years old until 20 years old (47.4\%; 227). Both of this age category were the majority of the respondents of this study. The remaining respondents are participated by students aged 31 to 40 years old $(1.3 \% ; 6)$, and 41 - 50 years old $(0.8 \% ; 4)$. The respondents in this study were only focused on the southern parts of Malaysia. Most of the respondents came from Universiti Teknologi MARA (UiTM) Melaka (36.7\%; 176), followed by Universiti Teknologi MARA (UiTM) Johor (36.7\%; 172), Universiti Teknikal Malaysia Melaka (UTeM) (10.4\%; 50), Universiti Teknologi Malaysia (UTM) (5.0\%; 24) and the least were from Universiti Tun Hussein Onn Malaysia (UTHM) (3.8\%; 18). 53.7\% or 257 of these students were currently doing their degree studies, and $46.3 \%$ or 222 were undergoing diploma studies. Generally, the respondents were also doing a full-time study mode with a value of $94.4 \%$ or 452 , while only $5.6 \%$ or 27 of the respondents were doing a part-time study. Apart from that, the research also shows that the majority of the respondents came from business studies, or were business students $(50.7 \%$ or 243 students), followed by IT \& Computer Sciences students (33.6\%; 161), Education Graduate \& Professional students (10.2\%; 49$)$, Integrative Studies students (3.8\%; 18$)$, Nursing students $(1.5 \% ; 7)$ and lastly, an Arts student $(0.2 \%$; 1).

\subsection{Reliability Analysis}

Table 2 determines the results of all the variables tested in the study. It shows a significant variation of Cronbach's Alpha values fluctuating from .843 to .954 . Supporting research was done by Nunally and Bernstein (1994) suggested that Cronbach's alpha values of greater than 0.70 is commonly regarded as desired or tolerable. This suggestion shows that the measurements of student behaviour, technological systems, interactive applications, institutional factors, instructor characteristics and acceptance were acceptable, valid and reliable.

Table 2: Reliability Statistics

\begin{tabular}{cccc}
\hline Variable & Cronbach's Alpha & $\begin{array}{c}\text { N of Items } \\
\text { Items }\end{array}$ & - \\
\hline Student Behavior & .859 & 5 & - \\
\hline Technology Systems & .843 & 5 & - \\
\hline Interactive Applications & .883 & 5 & 5 \\
\hline Institutional Factors & .881 & 5 & - \\
\hline Instructor Characteristics & .899 & 5 & - \\
\hline Acceptance & .954 & 5 & - \\
\hline
\end{tabular}

\subsection{Correlation Analysis}

Result of the Pearson's correlations between all variables is illustrated in Table 3 . All tested variables were positively and significantly correlated between variables $(p<.01)$. This indicates that all variable used in this study is having a stable association among each other. In term or the relation between acceptance and the student behaviour the result was ( $p=0.726)$. For acceptance and technology systems the result was $(p=0.638)$, acceptance and interactive application was $(p=0.757)$, acceptance and institutional factors was $(p=0.607)$ lastly, acceptance and instructor characteristics was $(\mathrm{p}=0.635)$. From all independent variables tested by the dependent variable, the 
relation between acceptance and interactive application were the highest, the relation between acceptance and the student behaviour are the second highest, followed by the relation between acceptance and the technology systems, in addition the relation between acceptance and instructor characteristics while the relation between acceptance and institutional factors were the lowest.

Table 3: Pearson Correlation Analysis

\begin{tabular}{|c|c|c|c|c|c|c|c|}
\hline Variable & & 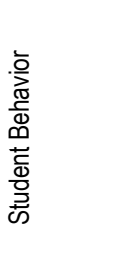 & 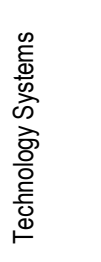 & 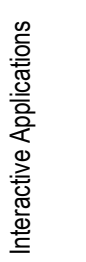 & 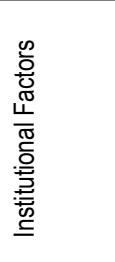 & 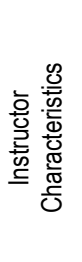 & 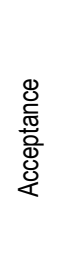 \\
\hline \multirow[t]{2}{*}{ Student Behavior } & Pearson Correlation & \multirow[t]{2}{*}{1} & & & & & \\
\hline & Sig. (2-tailed) & & & & & & \\
\hline \multirow[t]{2}{*}{ Technology Systems } & Pearson Correlation & $.715^{* *}$ & \multirow[t]{2}{*}{1} & $.743^{* *}$ & & & \\
\hline & Sig. (2-tailed) & .000 & & .000 & & & \\
\hline \multirow[t]{2}{*}{ Interactive Applications } & Pearson Correlation & $.760^{* *}$ & $.743^{* *}$ & \multirow[t]{2}{*}{1} & & & \\
\hline & Sig. (2-tailed) & .000 & .000 & & & & \\
\hline \multirow[t]{2}{*}{ Institutional Factors } & Pearson Correlation & $.627^{* *}$ & $.711^{* *}$ & $.645^{\star *}$ & \multirow[t]{2}{*}{1} & & \\
\hline & Sig. (2-tailed) & .000 & .000 & .000 & & & \\
\hline \multirow{2}{*}{$\begin{array}{c}\text { Instructor } \\
\text { Characteristics }\end{array}$} & Pearson Correlation & $.599^{* *}$ & $.622^{* *}$ & $.654^{* *}$ & $.668^{* *}$ & \multirow[b]{2}{*}{1} & \\
\hline & Sig. (2-tailed) & .000 & .000 & .000 & .000 & & \\
\hline \multirow[t]{2}{*}{ Acceptance } & Pearson Correlation & $.726^{* *}$ & $.638^{* *}$ & $.757^{\star *}$ & $.607^{* *}$ & $.635^{\star *}$ & \multirow[b]{2}{*}{1} \\
\hline & Sig. (2-tailed) & .000 & .000 & .000 & .000 & .000 & \\
\hline
\end{tabular}

\subsection{Regression Analysis}

Table 4: Multiple Regression Analysis

\begin{tabular}{|c|c|c|c|c|c|}
\hline \multicolumn{6}{|c|}{ Coefficients } \\
\hline \multirow[t]{3}{*}{ Model } & \multicolumn{2}{|c|}{$\begin{array}{l}\text { Unstandardized } \\
\text { Coefficients }\end{array}$} & \multirow{2}{*}{$\begin{array}{c}\text { Standardized } \\
\text { Coefficients } \\
\text { Beta }\end{array}$} & \multirow[t]{2}{*}{$t$} & \multirow[t]{2}{*}{ Sig. } \\
\hline & $B$ & Std. Error & & & \\
\hline & -.458 & .165 & & -2.782 & .006 \\
\hline Student Behavior & .396 & .060 & .301 & 6.635 & .000 \\
\hline $\begin{array}{l}\text { Technology } \\
\text { Systems }\end{array}$ & -.025 & .062 & -.019 & -.402 & .688 \\
\hline $\begin{array}{c}\text { Interactive } \\
\text { Applications }\end{array}$ & .433 & .054 & .388 & 7.981 & .000 \\
\hline Institutional Factors & .096 & .058 & .071 & 1.643 & .101 \\
\hline $\begin{array}{c}\text { Instructor } \\
\text { Characteristics }\end{array}$ & .208 & .050 & .165 & 4.117 & .000 \\
\hline
\end{tabular}

From the result, only three variables namely student behaviour, interactive application, and instructor characteristics were the significant predictors towards the acceptance of e-learning, the student behaviour, interactive application and instructor characteristics result were $(p=0.000)$. In contrast, technology systems $(p=0.688)$ and institutional factors $(p=0.101)$ were not the predictors towards acceptance. A session of regression analysis conducted to test the research objective; to observe the relationships between student behaviour, technology systems, interactive application, institutional factors, and instructor characteristics relationship with the acceptance of elearning among the distance learners in Malaysian southern universities. From the results, they show that interactive application is the most influencing variable towards the acceptance of e-learning usage with t-value of 7.981 and beta value of 0.433 , being the highest compared to other variables.

\subsection{Discussions}

The findings of this study revealed three variables which are student behaviour, interactive applications, and instructor characteristics is the most significant predictors towards the acceptance of e-learning among distance learners with these three variables achieve substantial values of 0.000 . However, the remaining two other variables have no significant predictors towards students' acceptance in e-learning, namely the technological systems and institutional factors - with substantial values of 0.688 and 0.101 , respectively. Several implications can be derived from this study to assist the lectures and Universities to develop a better content and medium for online learning. To meet with the student's demand, lectures can try to add some visual or audio in their teaching process to make the session more interactive while the lectures themselves must comply or equip themselves with the latest teaching method and technology to 
attract the student interest during the online lesson. However, all this will not be successful if the students themselves are not interested in learning.

\subsection{Conclusions and Recommendations}

Today's students do not have problems with technological and system because they have become accustomed to using this medium in their daily lives. They are even more familiar with supporting media social platforms such as Facebook, WhatsApp, Instagram and Telegram (Sankar, 2020). These platforms give advantages to learners and educators to easily share their knowledge through collaborative learning. Next, the institutional factor is relatable with online access to learning materials. Students can easily access the information at their fingertips by quickly searching for online learning materials. According to Oblinger and Oblinger (2005), most of the students these days depend on websites and internet archives as their primary sources in getting information. However, they still need basic guidelines for accessing online resources in their first attempt. Higher education institutions need to focus on studying related findings of student behaviour, interactive applications, and instructor characteristics to improve e-learning performance. Perspectives of the students must be recognized to measure the quality of education as they are the end-users of the products. Considering the response and acceptance of students towards online learning methods is very important because it is an indicator of performance to the success of the e-learning system developed by higher learning institutions. Apart from that, it also tests the ability of educators $s$ in conveying knowledge in new norms through the application of technology which will definitely challenge them. A prerequisite element for providing information and skill development is essential to provide a high education quality. The education standard involves two elements, namely learning materials, and delivery to the students. To ensure that e-learning process can be taken positively by both instructors and students, it depends on the institutional providers to offer a fine support structure that is also transferred into e-learning (Pullan, 2011).Support, cooperation and interaction from students and educators are also needed to ensure the effectiveness of this elearning platform in the future.As an extension to this study; it will be advantageous for other academic researchers from different countries with several other independent variables to measure the acceptance of e-learning

\section{Paper Contribution to Related Field of Study}

This research contributes to filling the gap of the existing literatures that are related to the study of e-learning acceptance among distance learners.

\section{Acknowledgments}

We would like to thank the survey respondents for taking their time to answer the questionnaire, and this paper's reviewers for their valuable comments.

\section{References}

Abd Aziz, N. A., Abd Aziz, N. N., Musa, M. H., Abdul Malik, S., Mohamad Khalid, R., \& ST MKom, N. N. (2020). Exploring BarriersContributing towards an Effective Online Learning among Undergraduates' Students using PLS-SEM. Environment-Behaviour Proceedings Journal, 5(15), 71-76. https://doi.org/10.21834/ebpj.v5i15.2511

Al-Adwan, A. \& Smedley, J. K. (2012). "Implementing e-learning in the Jordanian Higher Education Systems: Factors affecting impact". International Journal of Education and Development using Information and Communication Technology, 8 (1), pp121-135.

Asabere, N. and Enguah, S. (2012). "Use of Information \& Communication Technology (ICT) in Tertiary Education in Ghana: A Case Study of Electronic Learning (Elearning)". International Journal of Information and Communication Technology Research. 2(1), pp.62-68.

Aziz, N. A. A., Musa, M. H., Ghul, Z. H., Aziz, N. N. A., \& Khalid, R. M. (2018). D eterminants of UITM Johor student' behavioral intention to use e-learning system. International Journal of Engineering \& Technology, 7, 196-199.

Bawane, J., and Spector, J. M. (2009). Prioritization of online instructor roles: implications for competency-based teacher education programs. Distance Educ. 30, 383397.

Easton, S. S. (2003). Clarifying the instructor's role in online distance learning. Commun. Educ. 52, 87-105.

EGrandon, E., Alshare, O., \& Kwan, O. (2005). Factors influencing student intention to adopt online classes: A cross-cultural study.Journal of Computing Sciences in Colleges, 20(4), 46-56.ducation, 2, 105-113.

Folorunso, O., Ogunseye, O.S., \& Sharma, S.K. (2006). An exploratory study of the critical factors affecting the acceptability of e-learning in Nigerian universities. Information Management and Computer Security, 14(5), 496-505.

Gregory, M. S.-J., and Lodge, J. M. (2015). Academic workload: the silent barrier to the implementation of technology-enhanced learning strategies in higher education. Distance Educ. 36, 210-230.

Hong, K.S., Lai, K.W., \& Holton, D. (2003). Students' satisfaction and perceived learning with a Webbased course. Journal of Educational Technology \& Society 6(1). Retrieved January 15, 2004, from http://ifets.ieee.org/periodical/vol_1_2003/v_1_2003.html. 
Khamparia, A. \& Pandey, B., (2017). Impact of Interactive Multimedia in E-Learning Technologies: Role of Multimedia in E-Learning. Enhancing Academic Research with Knowledge Management Principles, Chapter 7, 199-227

Kilmurray, J. 2003. e-Learning: It's More Than Automation. The Technology Source (September/ October 2003). Retrieved on 10 December 2003. Available from http://ts.mivu.org/default.asp?show=article\&id=1014.

Koehler, M., Mishra, P. \& Yahya, K. (2007) 'Tracing the development of teacher knowledge in a design seminar: integrating content, pedagogy and technology', Computers \& Education, vol. 49 , no. 3 , pp. $740-76$

Koohang, A., and Durante, A. (2003). Learners' perceptions toward the web-based distance learning activities/assignments portion of anundergraduate hybrid instructional model. Journal of Informational Technology

Laurillard, D. (2002). Rethinking University Teaching: A Framework for the Effective Use of Educational Technology (2nd ed.). London: Routledge.

Lee, H. (2006). Creating a Knowledge-Based Society through E-Learning in Korea. Educational Technology Research and Development, 54(5), 529-540.

Liao, C. W., Chen, C. H., \& Shih, S. J. (2019). The interactivity of video and collaboration for learning achievement, intrin sic motivation, cognitive load, and behavior patterns in a digital game-based learning environment. Computers and Education, 133(1), 43-55.

Masrom, M. (2007). "Technology Acceptance Model and E-learning”. [Online]. Available at http://eprints.utm.my/5482/1/MaslinMasrom2006_techn.pdf. (Accessed on 27 Jul 2012).

Ndubisi, N.O. (2004). Factors influencing e-learning adoption intention: Examining the determinant structure of the decomposed theory of planned behaviour constructs Paper presented at the HERDSA 2004 Conference. (Miri, Sarawak, July, 4-7 2004). Retrieved January 27, 2021, from http://www.herdsa.org.au/conference2004/Contributions/RPap ers/P057-jt.pdf.

Ndubisi, N.O., \& Chukwunonso, N.C. (2004). On-line learning adoption intention: Comparing the predictive power of two competing models. Paper presented at the HERDSA 2004 Conference (Miri,Sarawak, July, 4-7 2004). Retrieved January 27, 2021, from http://herdsa2004.curtin.edu.my/ Contributions/RPapers/P058-jt.pdf

Nunnally, J. C., \& Bernstein, I. H. (1994). Psychometric theory (3rd edn). New York: McGraw-Hill.

Oblinger, D., \& Oblinger, J. (Eds.). (2005). Educating the Net Generation. Retrieved September 2009 from http://www.educause.edu/educatingthenetgen.

Oomen-Early, J., and Murphy, L. (2009). Self-actualization and e-learning: a qualitative investigation of university faculty's perceived barriers to effective online instruction. Int. J. E Learn. 8, 223-240

Passmore, D.L. (2000). Impediments to adoption of web-based course delivery among university faculty. ALN Magazine, 4 (2).

Poon, W.C., Low, L.T., \& Yong, G. F. (2004). A study of Web-based learning (WBL) environment in Malaysia. The International Journal of Educational Management, 18(6), 374-385

Pullan, M., (2011), Online Support Services for Undergraduate Millennial Students, Journal of Higher Education Theory and Practice vol. 11(2) 2011, 66-84

Rafaeli, S., \& Ravid, G. (1997). Online, web-based learning environment for an information systems course: Access logs, linearity and performance. Available online at http://mis.huji.ac.il/papers/mmm.paper.htm

Regehr, C., Glancy, D., and Pitts, A. (2013). Interventions to reduce stress in university students: a review and meta-analysis. J. Affect. Disord. 148, 1-11

Saade, R. G. (2003). Web-based education information system for enhanced learning, EISL: Student assessment. Journal of Information Technology Education, 2, 267277.

Sankar, J.P., Elumalai, K.V., et al., (2020). Factors Affecting the Quality of E-Learning During the COVID-19 Pandemic from the Perspective of Higher Education Students. Journal of Information Technology Education: Research 19(1):731-

Selim, H. M. (2003). An empirical investigation of student acceptance of course websites. Computers and Education, 40(4), 343-360

Shepherd, C. \& Mullane,A. M. (2010). Managing multimedia mania: Taming the technology beast. Journal of College Teaching \& Learning, 7, 59-70.

Sicilia, M., Ruiz, S., Munuera, J.L (2005). Effects of interactivity in a web site: the moderating effect of need for cognition, J. Advert., 34 (2005), pp. 31 $44,10.1080 / 00913367.2005 .10639202$

Stephenson, J. (2001). Teaching and learning online, pedagogies for new technologies. London, U.K.:Kogan Page Limited.

Tomas, L., Lasen, M., Field, E., \& Skamp, K. (2015). Promoting Online Students' Engagement and Learning in Science and Sustainability Preservice Teacher Education. Australian Journal of Teacher Education, 40(11). http://dx.doi.org/10.14221/ajte.2015v40n11.5

Volery, T., and Lord, D. (2000). Critical success factors in online education. Int. J. Educ. Manage. 14, 216-223.

Zhang, D., Zhao, L., Zhou, L., \& Nunamaker, J. (2004). Can e-learning replace classroom learning? Communication of the ACM, 47(5), 75-79. 